\title{
Morphoagronomic variation in natural populations of Trifolium riograndense (Burkart)
}

\author{
Ionara Fatima Conterato ${ }^{1}$; Miguel Dall’Agnol ${ }^{1}$; Maria Teresa Schifino-Wittmann ${ }^{1 *}$; Daniel \\ Portela Montardo²; Gabriel Colombo Pontalti ${ }^{1}$; Danielle Almeida ${ }^{1}$ \\ ${ }^{1}$ UFRGS/FA - Depto. de Plantas Forrageiras e Agrometeorologia, C.P. 15100 - 91501-970 - Porto Alegre, RS - \\ Brasil. \\ Embrapa Pecuária Sul, C.P. 242 - 96401-970 - Bagé, RS - Brasil. \\ *Corresponding author <mtschif@ufrgs.br>
}

\begin{abstract}
Several species of Trifolium are widely cultivated as forage for animals and green manure. This work aimed to characterize and estimate through morphological and agronomic traits the genetic diversity of natural populations of $T$. riograndense, an important forage legume from native pastures of the state of Rio Grande do Sul, Brazil. Plant height and diameter, number of primary and secondary stolons, stolon length, number of nodes per primary stolon, internode length, primary stolon diameter, leaf area, petiole length and dry matter production were analyzed in 29 accessions. The first five attributes and dry matter production were evaluated twice. A broad phenotypic variability was observed for almost all characteristics. Positive correlations occurred between petiole length and leaf area $(\mathrm{r}=0.68)$, petiole length and plant height in the first evaluation (0.63), stolon length and plant height (0.58), total dry matter and plant diameter $(0.61)$, and total dry matter and plant height in the second evaluation (0.55). The two most divergent accessions were collected in the same physiographic region and the two less divergent ones in different regions. A dissimilarity dendrogram separated four groups. Accessions collected in a region where T. riograndense is abundant were found to belong to different groups outlining the great variability of this native forage legume. Dry matter production in the first cut was the characteristic that most contributed $(20.80 \%)$ to accessions divergence followed by number of secondary stolons (12.30\%), leaf area (11.07\%), and number of nodes per primary stolon (10.93\%).

Key words: forage legume, genetic variability, morphology, plant breeding
\end{abstract}

\section{Variação morfoagronômica em populações naturais de Trifolium riograndense (Burkart)}

\begin{abstract}
RESUMO: Várias espécies de Trifolium são extensivamente cultivadas como forragem ou adubo verde. Caracterizaram-se e estimaram-se, por meio de atributos morfológicos e agronômicos, a diversidade genética de populações naturais de T. riograndense, importante leguminosa forrageira nativa dos campos naturais do Rio Grande do Sul. Estatura e diâmetro das plantas, número de estolões primários e secundários, comprimento do estolão primário, número de nós por estolão, comprimento dos entrenós, diâmetro de estolão, área foliar, tamanho do pecíolo e produção de massa seca foram avaliados em 29 acessos. Os cinco primeiros atributos e a produção de massa seca foram avaliados duas vezes. Ampla variabilidade fenotípica foi observada para quase todas as características. Ocorreram correlações positivas entre tamanho do pecíolo e área foliar $(\mathrm{r}=0,68)$, tamanho do pecíolo e estatura $(0,63)$ na primeira avaliação, e comprimento do estolão e estatura $(0,58)$, massa seca total e diâmetro da planta $(0,61)$ e massa seca total e estatura $(0,55)$ na segunda avaliação. Os dois acessos mais divergentes foram coletados na mesma região fisiográfica e os dois menos divergentes em regiões diferentes. O dendrograma de dissimilaridade genética separou quatro grupos. Acessos coletados em uma região onde $T$. riograndense é abundante pertenciam a diferentes grupos, o que realça a grande variabilidade dessa leguminosa forrageira nativa. A produção de massa seca no primeiro corte foi a característica que mais contribuiu $(20,80 \%)$ para a divergência dos acessos, seguida pelo número de estolões secundários (12,30\%), área foliar (11,07\%), e número de nós por estolão (10,93\%). Palavras-chave: leguminosa forrageira, variabilidade genética, morfologia, melhoramento
\end{abstract}

\section{Introduction}

The genus Trifolium L. (Leguminosae, Papilionoideae, Tribe Trifolieae) has its center of origin in the Mediterranean region with around 255 annual and perennial, autogamous and allogamous species, distributed in temperate and subtropical areas. Several of these species, such as $T$. repens L., T. pratense L., $T$. bybridum L. T. vesiculosum Savi and T. incarnatum L, are widely cultivated as forage for animals and green manure. (Zohary and Heller, 1984). T. riograndense Burkart, popularly known as "trevo riograndense", an important component of natural pastures of Southern Brazil, is a perennial, diploid $(2 \mathrm{n}=2 \mathrm{x}=16)$ (Schifino, 1983; Schifino and Moraes-Fernandes, 1988), allogamous and versatile (may also self-pollinate) species (Becker et al., 1987). Be- 
sides growing during winter and providing a good quality forage for cattle in this period, improves soil fertility by nitrogen fixation. The quality that most attracts agronomists and plant breeders is its tolerance to acid, aluminum and manganese rich soils. Natural populations are widespread in Southern Brazil (Kappel, 1967).

The present focus in sustainable cattle raising plus the difficulty to obtain interspecific hybrids in Trifolium is raising the interest to evaluate locally adapted species (Ellison et al., 2006) and T. riograndense is included in this context. In order to obtain a wider utilization and breeding of this species it is necessary to characterize its variability and productive potential. Despite previous works with the species (e.g. Becker et al., 1987; Schifino and Moraes-Fernandes, 1987, 1988; Souza et al., 1988; Moraes et al. 1989) no comprehensive study to as- sess its genetic variability has been made. Therefore, this work aimed to characterize and estimate through morphological and agronomic traits the genetic diversity of natural populations of $T$. riograndense.

\section{Material and Methods}

Seeds from several populations (accessions) of $T$. riograndense were collected in different areas of its natural distribution in Southern Braziland were kept as part of a germplasm collection. From these, 29 accessions, representative of the area of the species distribution and with enough number of seeds for the experiment, were analyzed (Figure 1, Table 1).

In May 2008, 25 to 30 seeds of each accession, after mechanical scarification, were germinated in Petri dishes

Table 1 - Accessions of T. riograndense analyzed, including place of collection (municipality) and respective physiographic region.

\begin{tabular}{|c|c|c|}
\hline Accession & Place of collection* & Physiographic region*** \\
\hline 01 & S. F. Paula $\left(29^{\circ} 26^{\prime} \mathrm{S}, 50^{\circ} 35^{\prime} \mathrm{W}\right)$ & C. Cima da Serra \\
\hline 03 & Mormaço $\left(28^{\circ} 41^{\prime} \mathrm{S}, 52^{\circ} 41^{\prime} \mathrm{W}\right)$ & Planalto Médio \\
\hline 10 & Lagoa Vermelha $\left(28^{\circ} 12^{\prime} \mathrm{S}, 51^{\circ} 31^{\prime} \mathrm{W}\right)$ & C. Cima da Serra \\
\hline 11 & S.F.Paula $\left(29^{\circ} 26^{\prime}\right.$ S, $\left.50^{\circ} 35^{\prime} \mathrm{W}\right)$ & C. Cima da Serra \\
\hline 15 & Passo Fundo $\left(28^{\circ} 15^{\prime} \mathrm{S}, 52^{\circ} 24^{\prime} \mathrm{W}\right)$ & Planalto Médio \\
\hline 17 & Seberi $\left(27^{\circ} 28^{\prime} \mathrm{S}, 53^{\circ} 24^{\prime} \mathrm{W}\right)$ & Alto Uruguai \\
\hline 18 & Frederico Westphalen $\left(27^{\circ} 21^{\prime} \mathrm{S}, 53^{\circ} 23^{\prime} \mathrm{W}\right)$ & Alto Uruguai \\
\hline 19 & Tenente Portela $\left(27^{\circ} 22^{\prime} \mathrm{S}, 53^{\circ} 45^{\prime} \mathrm{W}\right)$ & Alto Uruguai \\
\hline 20 & Bom Jesus $\left(28^{\circ} 40^{\prime} \mathrm{S}, 50^{\circ} 25^{\prime} \mathrm{W}\right)$ & C. Cima da Serra \\
\hline 21 & Passo Fundo $\left(28^{\circ} 15^{\prime} \mathrm{S}, 52^{\circ} 24^{\prime} \mathrm{W}\right)$ & Alto Uruguai \\
\hline 23 & Boa Vista das Missões $\left(27^{\circ} 39^{\prime} \mathrm{S}, 5^{\circ}{ }^{\circ} 8^{\prime} \mathrm{W}\right)$ & Planalto Médio \\
\hline 29 & Muitos Capões $\left(28^{\circ} 18^{\prime} \mathrm{S}, 51^{\circ} 10^{\prime} \mathrm{W}\right)$ & C. Cima da Serra \\
\hline 30 & Tio Hugo $\left(28^{\circ} 34^{\prime} \mathrm{S}, 52^{\circ} 35^{\prime} \mathrm{W}\right)$ & Planalto Médio \\
\hline 33 & Palmeira das Missões $\left(27^{\circ} 53^{\prime} \mathrm{S}, 53^{\circ} 18^{\prime} \mathrm{W}\right)$ & Planalto Médio \\
\hline 41 & Lagoa Vermelha $\left(28^{\circ} 12^{\prime} \mathrm{S}, 51^{\circ} 31^{\prime} \mathrm{W}\right)$ & C. Cima da Serra \\
\hline 42 & Frederico Westphalen $\left(27^{\circ} 21^{\prime} \mathrm{S}, 53^{\circ} 23^{\prime} \mathrm{W}\right)$ & Alto Uruguai \\
\hline 43 & 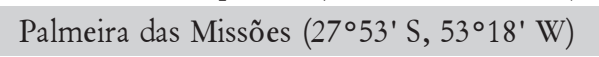 & Planalto Médio \\
\hline 45 & Panambi $\left(28^{\circ} 17^{\prime} \mathrm{S}, 53^{\circ} 30^{\prime} \mathrm{W}\right)$ & Planalto Médio \\
\hline 46 & Cruz Alta $\left(28^{\circ} 38^{\prime} \mathrm{S}, 53^{\circ} 36^{\prime} \mathrm{W}\right)$ & Planalto Médio \\
\hline 47 & Tupanciretã $\left(29^{\circ} 04^{\prime} \mathrm{S}, 53^{\circ} 50^{\prime} \mathrm{W}\right)$ & Planalto Médio \\
\hline 49 & Itaara $\left(29^{\circ} 36^{\prime} \mathrm{S}, 53^{\circ} 45^{\prime} \mathrm{W}\right)$ & D. Central \\
\hline 50 & Lajeado Grande $\left(29^{\circ} 26^{\prime} \mathrm{S}, 50^{\circ} 35^{\prime} \mathrm{W}\right)$ & C. Cima da Serra \\
\hline 53 & Lajeado Grande $\left(29^{\circ} 26^{\prime} \mathrm{S}, 5^{\circ} 35^{\prime} \mathrm{W}\right)$ & C.Cima da Serra \\
\hline 59 & Lajeado Grande $\left(29^{\circ} 26^{\prime} \mathrm{S}, 50^{\circ} 35^{\prime} \mathrm{W}\right)$ & C. Cima da Serra \\
\hline 64 & Tainhas $\left(29^{\circ} 26^{\prime} \mathrm{S}, 50^{\circ} 35^{\prime} \mathrm{W}\right)$ & C. Cima da Serra \\
\hline 66 & Tainhas $\left(29^{\circ} 26^{\prime} \mathrm{S}, 50^{\circ} 35^{\prime} \mathrm{W}\right)$ & C. Cima da Serra \\
\hline 67 & Tainhas $\left(29^{\circ} 26^{\prime} \mathrm{S}, 50^{\circ} 35^{\prime} \mathrm{W}\right)$ & C. Cima da Serra \\
\hline 71 & Tainhas $\left(29^{\circ} 26^{\prime} \mathrm{S}, 50^{\circ} 35^{\prime} \mathrm{W}\right)$ & C. Cima da Serra \\
\hline 72 & S. F.Paula $\left(29^{\circ} 26^{\prime} \mathrm{S}, 50^{\circ} 35^{\prime} \mathrm{W}\right)$ & C. Cima da Serra \\
\hline
\end{tabular}

*S. F. Paula: São Francisco de Paula municipality; *Tainhas and Lajeado Grande are districts from São Francisco de Paula; ** C. Cima da Serra: Campos de Cima da Serra; D. Central: Depressão Central. 


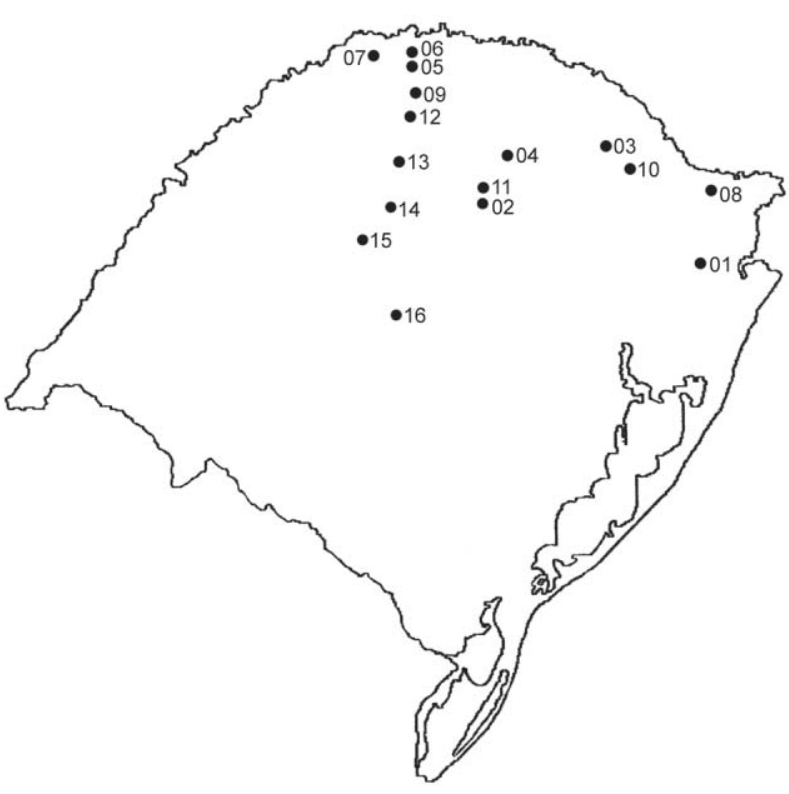

Figure 1 - Map of Rio Grande do Sul State, Brazil, with the collection sites of $T$. riograndense accessions detailed in Table 1: 01 - São Francisco de Paula (accessions 01, 11, 50, 53, 59, 66, 67, 71, 72), 02 - Mormaço (accession 03), 03 - Lagoa Vermelha (accessions 10, 41), 04 - Passo Fundo (accessions 15, 21), 05 - Seberi (accession 17), 06 - Frederico Westphalen (accessions 18, 42), 07 - Tenente Portela (accession 19), 08 Bom Jesus (accession 20), 09 - Boa Vista das Missões (accession 23), 10 - Muitos Capões (accession 29), 11 - Tio Hugo (accession 30),12 - Palmeira das Missões (accessions 33, 43), 13 - Panambi (accession 45), 14 - Cruz Alta (accession 46), 15 - Tupanciretã (accession 47), 16 - Itaara (accession 49).

lined with moist filter paper. Seedlings were transferred to styrophoam containers with commercial substrate and later to plastic cups with garden soil. In August the young plants were transferred to plastic pots with 1.25 $\mathrm{kg}$ of garden soil. Finally at the end of September, they were planted in plastic boxes $(34 \mathrm{~cm} \times 14 \mathrm{~cm} \times 11.5$ $\mathrm{cm})$ with garden soil, one plant per box. The boxes were arranged in a field area $\left(30^{\circ} 02^{\prime} \mathrm{S}, 51^{\circ} 13^{\prime} \mathrm{W}\right)$ in Porto Alegre, state of Rio Grande do Sul, Brazil, in a completely randomized design, with ten repetitions. Each box was considered as an experimental unit.

The following characteristics were evaluated: plant height (PLH), plant diameter (PLD), number of primary (STL1) and secondary stolons (STL2), primary stolon length (STL1L), number of nodes per primary stolon $(\mathrm{NN})$, internode length (INL), primary stolon diameter (STLD), petiole length (PEL), leaf area (LEA) and dry matter production (DMP). Length and height measurements were made with a centimered rule. Internode length was calculated dividing each primary stolon length by its number of nodes. Primary stolon diameter was measured with a pachymeter, at the beginning of the first internode. For leaf area, four leaves (12 leaflets) were measured per plant with a LICOR 3100 optical planimeter.
Two evaluations were performed (separated by a cut in the $25^{\text {th }}$ and $26^{\text {th }}$ October): in the second week of October 2008 and in the second week of December 2008. Characters PLH, PLD, STL1, STL2, STL1L, NN, INL, STLD, PEL and LEA were assessed in the first evaluation. In the second evaluation (named B), plant height (PLHB), plant diameter (PLDB), primary (STL1B) and secondary (STL2B) stolons number, primary stolons length (STL1LB) were determined.

Dry matter production evaluation was performed by two cuts, the first at $25^{\text {th }}$ and $26^{\text {th }}$ October (DMP1) and the second (DMP2) in the middle of December, immediately after the end of the second measurements evaluation. The plants were individually cut at $2.0 \mathrm{~cm}$ from the soil, and kept in paper bags at $60^{\circ} \mathrm{C}$ for $72 \mathrm{~h}$.

The data was analyzed by a multivariate analysis taken in account all the traits studided, using the Genes Program (Cruz, 2001) generating a dissimilarity matrix using the Mahalanobis distance. The relative importance of each characteristic was established by the method of Sing and afterwards the accessions were grouped by their similarity by the method of Tocher. A simple linear correlation analysis (Pearson) was made using the average values for each characteristic analysis employing the SANEST (Alves et al., 1993) statistical package. A dendrogram of genetic dissimilarity based on all the analyzed characteristics was generated based on the average Euclidian distance with the aid of the NTSYS-PC (Numerical Taxonomy and Multivariate Analysis System) (Rolfh, 2001) program.

\section{Results and Discussion}

The collection of $T$. riograndense accessions had a broad phenotypic variability for most of the examined characteristics (Tables 2 and 3). For example, leaf area ranged from 2.02 to $4.30 \mathrm{~cm}^{2}$ and the accessions could be classified by leaf size in three groups: "large leaves' (more than $3.12 \mathrm{~cm}^{2}$ ), including accessions 17, 43, 46, 49, 50 and 71, "intermediate leaves" (between 2.50 and 3.12 $\mathrm{cm}^{2}$ ), with accessions $1,15,21,23,29,33,41,42,47,59$, 67 and 69, and "small leaves" (less than $2.50 \mathrm{~cm}^{2}$ ), with accessions 3, 10, 11, 18, 19, 20, 30, 45, 53, 64, 66 and 72. Accessions in the group of large leaves presented larger petioles while those of the small- leafed group had smaller petioles. Leaf area also allows classification (Bortolini et al., 2006) of populations in groups in other species, as in white clover (T. repens). Analyzing a collection of 78 populations of white clover, Bortolini et al. (2006) separated the accessions in three groups: "large leaves" (more than $11.20 \mathrm{~cm}^{2}$ ), "intermediate leaves" (4.09 to $11.20 \mathrm{~cm}^{2}$ ) and "small leaves" (up to $4.09 \mathrm{~cm}^{2}$ ).

The results of the present work will be discussed, when possible, in comparison to those on white clover (Trifolium repens L.). The reasons for this kind of comparison are manyfold: (i) there are no similar studies as the present one for T. riograndense; (ii) both species have similar growing habits, are stoloniferous and perennial; (iii) white clover is widely cultivated around the world 
Table 2 - Average values for the characteristics analyzed in T. riograndense in the first evaluation.

\begin{tabular}{|c|c|c|c|c|c|c|c|c|c|c|c|}
\hline Accession & GR & PLH & PLD & STL1 & STL2 & STL1L & $\mathrm{NN}$ & LEA & STLD & PEL & DMP1 \\
\hline & \multicolumn{4}{|c|}{-...- cm - } & \multicolumn{3}{|c|}{$\mathrm{cm}$} & $\mathrm{cm}^{2}$ & $\mathrm{~mm}$ & $\mathrm{~cm}$ & $\mathrm{~g}$ \\
\hline 1 & 1 & 4.3 & 9.5 & 4.0 & 1.5 & 5.1 & 5.1 & 2.55 & 2.0 & 4.05 & 0.74 \\
\hline 3 & 6 & 4.2 & 11.8 & 3.9 & 1.7 & 6.20 & 5.0 & 2.35 & 1.9 & 3.27 & 0.52 \\
\hline 10 & 2 & 3.3 & 11.4 & 3.8 & 1.3 & 6.0 & 5.3 & 2.02 & 1.5 & 2.85 & 0.38 \\
\hline 11 & 3 & 4.1 & 6.8 & 2.5 & 0.1 & 3.8 & 3.7 & 2.15 & 1.5 & 3.42 & 0.28 \\
\hline 15 & 4 & 3.4 & 7.1 & 1.9 & 0.5 & 3.4 & 3.4 & 2.55 & 1.3 & 3.9 & 0.41 \\
\hline 17 & 7 & 6.0 & 15.5 & 4.2 & 2.1 & 7.3 & 5.4 & 3.92 & 1.9 & 5.17 & 0.89 \\
\hline 18 & 2 & 4.7 & 9.4 & 3.8 & 1.8 & 5.2 & 5.2 & 2.47 & 1.8 & 3.8 & 0.61 \\
\hline 19 & 3 & 4.6 & 12.4 & 4.7 & 3.3 & 7.2 & 6.0 & 2.22 & 1.8 & 3.5 & 0.61 \\
\hline 20 & 6 & 3.0 & 9.7 & 3.1 & 1.3 & 5.3 & 5.2 & 2.27 & 1.8 & 2.97 & 0.44 \\
\hline 21 & 11 & 4.6 & 5.0 & 1.9 & 0.1 & 2.4 & 2.5 & 2.97 & 1.2 & 3.87 & 0.28 \\
\hline 23 & 9 & 5.8 & 14.9 & 3.8 & 3.6 & 7.2 & 5.2 & 3.05 & 2.0 & 4.6 & 0.75 \\
\hline 29 & 1 & 4.4 & 6.3 & 2.9 & 0.1 & 3.1 & 3.4 & 2.82 & 1.9 & 3.85 & 0.44 \\
\hline 30 & 5 & 4.9 & 10.6 & 3.8 & 1.4 & 5.6 & 5.3 & 2.47 & 2.0 & 3.82 & 0.59 \\
\hline 33 & 4 & 4.8 & 6.9 & 2.3 & 0.0 & 4.0 & 4.0 & 2.8 & 1.9 & 4.0 & 0.47 \\
\hline 41 & 2 & 3.8 & 9.9 & 2.4 & 0.8 & 5.3 & 4.4 & 2.55 & 1.7 & 3.87 & 0.58 \\
\hline 42 & 1 & 5.0 & 11.5 & 3.9 & 3.5 & 6.0 & 5.1 & 3.12 & 1.9 & 3.82 & 0.71 \\
\hline 43 & 7 & 6.2 & 20.5 & 4.7 & 9.8 & 11.6 & 8.0 & 4.3 & 2.0 & 4.87 & 1.7 \\
\hline 45 & 3 & 3.7 & 4.5 & 3.1 & 1.5 & 3.5 & 3.6 & 2.3 & 1.9 & 3.65 & 0.31 \\
\hline 46 & 10 & 6.8 & 14.9 & 3.6 & 5.5 & 8.0 & 6.2 & 3.62 & 2.0 & 5.27 & 1.07 \\
\hline 47 & 5 & 4.3 & 11.6 & 3.7 & 2.2 & 6.6 & 5.2 & 2.52 & 2.0 & 3.92 & 0.54 \\
\hline 49 & 8 & 5.9 & 16.1 & 4.6 & 2.8 & 8.2 & 5.7 & 3.75 & 2.1 & 4.75 & 1.11 \\
\hline 50 & 5 & 4.7 & 23.3 & 4.9 & 14.8 & 12.8 & 8.8 & 3.27 & 1.9 & 4.0 & 1.44 \\
\hline 53 & 2 & 3.9 & 21.6 & 4.5 & 8.4 & 12.2 & 8.0 & 2.4 & 1.8 & 3.55 & 0.65 \\
\hline 59 & 1 & 3.9 & 19.4 & 3.4 & 5.2 & 9.9 & 7.1 & 2.9 & 1.9 & 4.4 & 0.88 \\
\hline 64 & 9 & 4.6 & 11.1 & 4.4 & 3.6 & 5.9 & 5.6 & 2.25 & 1.9 & 3.5 & 0.49 \\
\hline 66 & 1 & 4.4 & 14.5 & 4.6 & 4.4 & 7.5 & 6.3 & 2.3 & 1.8 & 3.65 & 0.8 \\
\hline 67 & 12 & 5.6 & 19.1 & 4.7 & 10.6 & 9.6 & 7.7 & 3.0 & 1.8 & 4.87 & 1.45 \\
\hline 71 & 8 & 4.3 & 28.20 & 4.5 & 19.3 & 15.6 & 10.4 & 3.65 & 2.0 & 4.22 & 2.0 \\
\hline 72 & 13 & 3.3 & 11.2 & 3.1 & 3.6 & 5.7 & 5.7 & 2.57 & 1.9 & 3.30 & 0.6 \\
\hline
\end{tabular}

GR: Tocher groups; PLH: plant height, PLD: plant diameter; STL1: number of primary stolons; STL2: number of secondary stolons, STL1L: primary stolon length; NN: number of nodes; LEA: leaf area; STLD: stolon diameter; PEL: petiole length; DMP1: dry matter production, first cut.

and is a well studied and characterized species (Nabinger, 1980; Alcântara and Bufarah, 1988; Mather et al., 1995; Jahufer et al., 2002; Schneiter et al., 2009).

For primary stolon length (STL1), in the first evaluation, the higher values were found for accessions 71,50 (large-leafed group) and 53 (small-leafed group) (15.6, 12.8 and $12.2 \mathrm{~cm}$, respectively), which also presented the higher number of nodes per primary stolon $(\mathrm{NN})(10.4$, 8.8 and 8.0 nodes, respectively). Accessions 71 e 53 also had the highest internode length (INL) $(1.5 \mathrm{~cm}$ for both). These three accessions were those with smaller plant height in the second evaluation (Table 3), which agrees with Bortolini et al. (2006) for white clover, who reported that genotypes with a higher number of nodes had a prostrate habit. The smaller stolon lengths were found in ac- cessions 21 and 29 (2.4 and $3.1 \mathrm{~cm}$, respectively) and the smaller number of nodes in accessions 21 (2.5 nodes), 15 and 29 (3.4 nodes) (Table 2). Stolon diameter (STLD) varied little among accessions ranging from $1.3 \mathrm{~mm}$ to $2.0 \mathrm{~mm}$. In white clover stolon diameter is more variable: $1.4 \mathrm{~mm}$ to $3.7 \mathrm{~mm}$ (Rosso and Pagano, 2001), 2.0 $\mathrm{mm}$ to $3.0 \mathrm{~mm}$ (Flores et al., 2004), $1.5 \mathrm{~mm}$ to $2.8 \mathrm{~mm}$ (Bortolini et al., 2006) and plants with thicker stolons tend to be higher, with larger leaves and flowers (Flores et al., 2004). In the present study, no relation between stolon diameter and plant or leaf size could be detected. Plants of $T$. riograndense are generally more prostrate and smaller than those of white clover.

In the first evaluation, accessions with the highest plant height (PLH) were 46, 43 and 17 (6.8, 6.2 and 6.0 
Table 3 - Average values for the characteristics analyzed in T. riograndense in the second evaluation (B).

\begin{tabular}{|c|c|c|c|c|c|c|c|c|}
\hline Accession & GR & PLHB & PLDB & STL1B & STL2B & STL1B & DMP2 & TDMP \\
\hline \multicolumn{6}{|c|}{ cm - cm } & $\mathrm{cm}$ & \multicolumn{2}{|c|}{ g } \\
\hline 1 & 1 & 4.1 & 52.0 & 4.9 & 30.4 & 25.61 & 5.8 & 6.5 \\
\hline 3 & 6 & 5.4 & 55.8 & 5.4 & 35.4 & 28.83 & 5.51 & 6.03 \\
\hline 10 & 2 & 5.1 & 53.7 & 5.6 & 37.4 & 30.0 & 3.54 & 3.92 \\
\hline 11 & 3 & 5.8 & 52.4 & 5.0 & 36.4 & 26.5 & 4.6 & 4.88 \\
\hline 15 & 4 & 5.9 & 46.1 & 4.1 & 23.2 & 23.61 & 5.63 & 6.04 \\
\hline 17 & 7 & 5.7 & 46.9 & 4.4 & 26.2 & 24.8 & 4.32 & 5.21 \\
\hline 18 & 2 & 5.2 & 62.9 & 5.5 & 39.8 & 32.83 & 3.09 & 3.7 \\
\hline 19 & 3 & 5.8 & 46.4 & 5.1 & 28.5 & 25.0 & 4.9 & 5.34 \\
\hline 20 & 6 & 5.0 & 55.1 & 5.2 & 30.8 & 28.33 & 3.19 & 3.47 \\
\hline 21 & 11 & 5.4 & 39.1 & 4.1 & 25.5 & 22.5 & 5.71 & 6.46 \\
\hline 23 & 9 & 5.4 & 64.5 & 4.9 & 34.9 & 32.25 & 3.61 & 4.05 \\
\hline 29 & 1 & 5.9 & 46.7 & 4.6 & 30.4 & 26.13 & 6.76 & 7.35 \\
\hline 30 & 5 & 7.0 & 56.3 & 5.4 & 33.7 & 27.08 & 6.52 & 6.99 \\
\hline 33 & 4 & 6.6 & 61.1 & 4.8 & 33.8 & 32.44 & 8.15 & 8.73 \\
\hline 41 & 2 & 6.1 & 59.5 & 4.7 & 32.4 & 29.72 & 5.11 & 5.82 \\
\hline 42 & 1 & 5.3 & 48.5 & 4.6 & 28.6 & 25.15 & 4.63 & 6.33 \\
\hline 43 & 7 & 6.0 & 50.5 & 3.7 & 24.4 & 25.3 & 4.18 & 4.51 \\
\hline 45 & 3 & 4.5 & 43.0 & 4.3 & 25.9 & 22.05 & 6.15 & 7.22 \\
\hline 46 & 10 & 6.5 & 62.4 & 5.2 & 38.0 & 32.4 & 6.26 & 6.8 \\
\hline 47 & 5 & 6.8 & 64.3 & 5.7 & 39.9 & 33.3 & 5.15 & 6.26 \\
\hline 49 & 8 & 6.3 & 63.0 & 5.1 & 35.6 & 32.0 & 4.15 & 5.59 \\
\hline 50 & 5 & 4.2 & 56.3 & 4.8 & 30.3 & 27.44 & 2.26 & 2.91 \\
\hline 53 & 2 & 3.8 & 45.4 & 3.9 & 20.7 & 24.57 & 4.28 & 5.16 \\
\hline 59 & 1 & 4.6 & 61.8 & 4.5 & 34.4 & 30.5 & 3.24 & 3.74 \\
\hline 64 & 9 & 5.4 & 41.1 & 4.4 & 22.8 & 21.35 & 6.12 & 6.92 \\
\hline 66 & 1 & 6.8 & 55.3 & 5.6 & 34.4 & 28.1 & 5.97 & 7.43 \\
\hline 67 & 12 & 5.8 & 57.1 & 5.3 & 31.1 & 27.6 & 6.33 & 8.33 \\
\hline 71 & 8 & 5.0 & 61.7 & 5.3 & 36.8 & 30.83 & 3.08 & 3.68 \\
\hline 72 & 13 & 4.1 & 39.9 & 4.0 & 23.3 & 23.38 & 4.41 & 5.02 \\
\hline
\end{tabular}

GR: Tocher groups; PLHB: plant height; PLDB: plant diameter; STL1B: number of primary stolons; STL2B: number of secondary stolons; STL1B primary stolons length; DMP2: dry matter production, second cut; TDMP: total dry matter production.

$\mathrm{cm}$, respectively) and those with smaller plants were 72 , 10 and 15 (3.3, 3.3 and $3.2 \mathrm{~cm}$, respectively) (Table 2). In the second evaluation, considering regrowth after the first cut, plant height values (PLHB) were the highest in accessions 30,66 and 47 (7.0, 6.8 and $6.8 \mathrm{~cm}$, respectively) and the lowest in accessions 1,53 and 72 (4.1,3.8 and 4.1 $\mathrm{cm}$, respectively) (Table 3). Accession 72 also presented a small plant diameter and a low number of primary stolons $(39.9$ and $4.0 \mathrm{~cm}$ ) when compared with the other accessions (Table 3 ). The accessions with the tallest plants in the first evaluation (46, 43 and 17) were of the large-leafed group, but two of the accessions with the tallest plants (30 and 66) are of the small-leafed group. These results indicate the plasticity of this characteristic (height) in T. riograndense.
The highest average values for plant diameter in the first evaluation (PLD) were observed in accessions 71, 50 and $53(28.2,23.0$ and $21.6 \mathrm{~cm}$, respectively) and in accessions 23,47 and 49 (64.5, 64.3 and 63.0, respectively) in the second evaluation (PLDB) (Tables 2 and 3). Accession 47 also presented the highest number of primary (5.7) and secondary (39.9) stolons in the second evaluation (Table 3) and 71 the highest number of secondary stolons (19.3, Table 2) in the first evaluation. The lowest plant diameters were recorded in accessions 45 and 21 (4.5 and $5.0 \mathrm{~cm}$, respectively) in the first evaluation (Table 2) and in accessions 21 and $72(39.1$ and $39.9 \mathrm{~cm}$, respectively) in the second evaluation (Table 3 ). In the first evaluation, the highest number of primary stolons (STL1) was found in accessions 50 (4.9) and 67, 43 and 
19 (4.7) and of secondary stolons (STL2) in accessions 71, 50 and 67 (19.3, 14.8 and 10.6, respectively) (Table 2) while the lowest values of STL1 and STL2 in the first evaluation were observed in accessions 15 and 21 (1.9) and 12 (2.5), and 11, 21 and 29 (0.1), respectively (Table 2 ). In the second evaluation the lowest values of STL1 and STL2 were found in accessions 43, 53 and 72 (3.7, 3.9 and 4.0$)$ and 53, 64 and 15 (20.7, 22.8 and 23.2) respectively (Table 3 ).

Considering dry matter production (DMP1 and DMP2) in the two evaluations, accessions 43,50 and 71 , all of them of the large-leafed group, were the most productive in the first cut $(1.70,1.44$ e $2.00 \mathrm{~g} \mathrm{DM}$, respectively) (Table 2) but not in the second cut $(4.18,2.26$ and $3.08 \mathrm{~g}$ ) nor in the total (DMT) production (4.51, 2.91 and $3.68 \mathrm{~g}$ ) (Table 3). A possible explanation is that these accessions would have an earlier vegetative cycle compared to the others. The accessions with a total dry matter production over $7.0 \mathrm{~g}$ per plant were $33,67,66,29$ and $45(8.73,8.33,7.43,7.35$ and $7.22 \mathrm{~g})$, included in the intermediate and small-leafed groups. Data suggests that, in $T$. riograndense, accessions precocious in production have larger leaves and less total dry matter. In white clover, Bortolini et al. (2006) verified that plants starting to produce earlier where those with higher total dry matter production.
Correlation coefficients analysis (Table 4) disclosed positive correlations between stolon length and plant diameter $(r=0.93)$, number of nodes per stolon and stolon length $(r=0.88)$ and number of nodes per stolon and plant diameter $(r=0.83)$ in the first evaluation, indicating that stolon growth leads to an increase in plant diameter and number of nodes per stolon as was already mentioned by Souza et al. (1988) in five accessions of $T$. riograndense. Stolon growth and its ramifications are linked to plant persistence and percentage of soil covering, as reported by Moraes et al. (1989) in T. riograndense and Thomas (1980) in white clover. In field conditions, shorter internodes characterized white clover plants with shorter stolons and, consequently, shorter stolons per area unit, favouring persistence, as a higher number of nodes increases rooting and vegetative propagation (Flores et al., 2004). However, longer internodes would avoid photosynthesis limitation by shadowing from associated species (Albert and Simms, 2002).

White clover persistence is mainly due to stolons growth, therefore persistence of the species requires an adequate management to keep a certain stolon length and size (Sanderson et al., 2003). This could be also applied to $T$. riograndense as this species is found in the natural pastures associated with other species, such as summer grasses, and its persistence is related to a continuous production of stolons and seeds (Nabinger, 2006).

Table 4 - Simple linear correlations among the analyzed characteristics im T. riograndense: first evaluation: PLH (plant height), PLD (plant diameter), STL1 (number of primary stolons, STL2 (number of secondary stolons), STL1L (primary stolons length), NN (number of nodes per stolon), INL (internode length), STLD (stolon diameter), LEA (leaf area), PEL (petiole length), DMP1 (dry matter production, first cut); second evaluation: PLDB (plant diameter), PLHB (plant height), STL1B (number of primary stolons), STL2B (number of secondary stolons), STL1LB (length of primary stolons), DMP2 (dry matter production, second cut) and TDMP (total dry matter production).

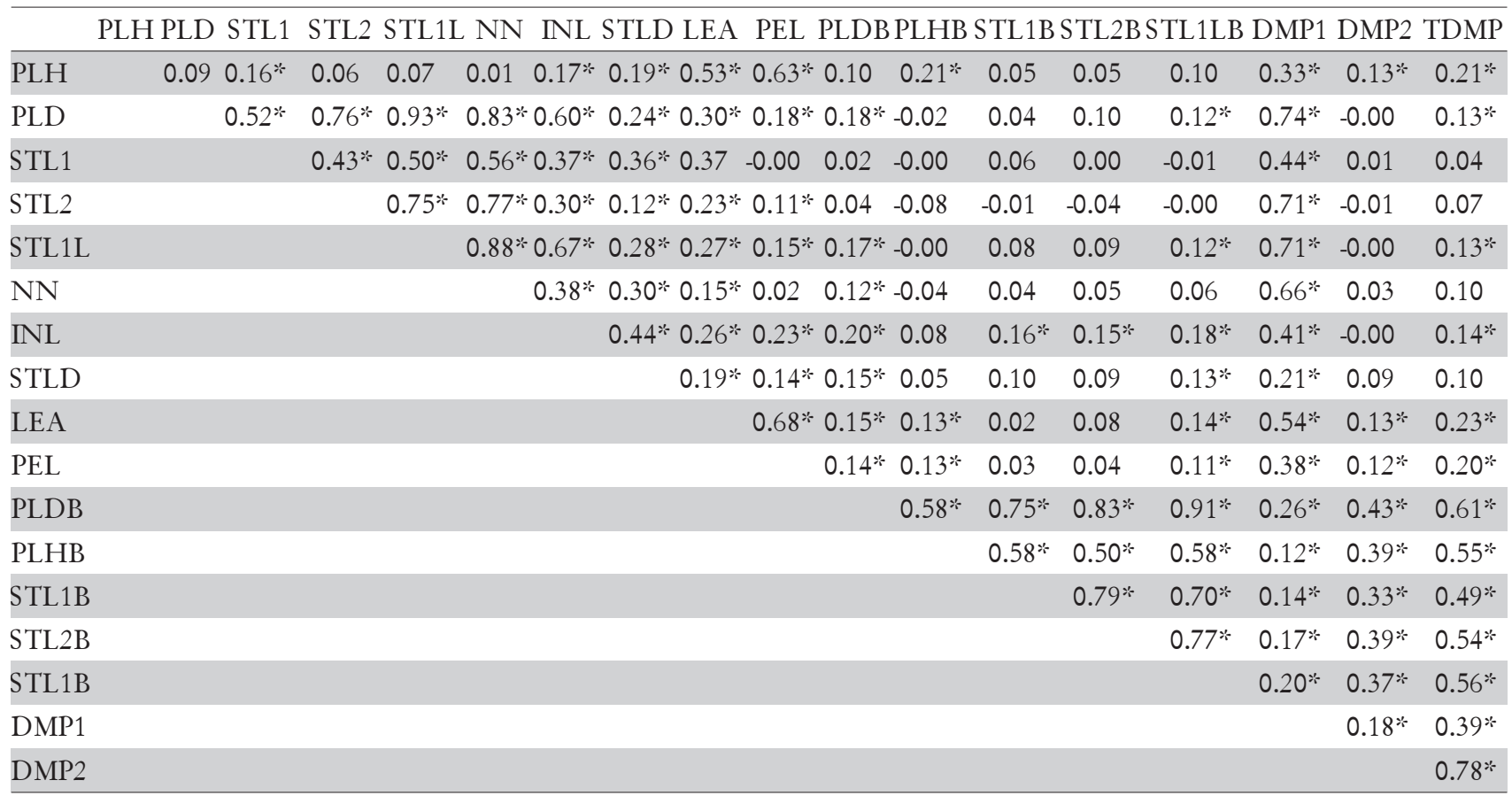

*Significant at $5 \%$ probability, $\mathrm{t}$ test $(p<0.05)$. 
Petiole length and leaf area $(r=0.68)$ and petiole length and plant height $(r=0.63)$ were also positively correlated in the first evaluation (Table 4). Bortolini et al. (2006) reported a positive correlation between plant height and leaf area in white clover suggesting that plants with larger leaf area also had higher petioles. In red clover, Dias et al. (2008) verified that plants with larger leaf area were higher. Other works with white clover also showed correlation between leaf area and petiole length (Gustine et al., 2002) and between leaf length and plant heigth (Mather et al., 1995). Rosso and Pagano (2005) reported that white clover populations under grazing have small leaves and low stature.Stolon diameter was poorly correlated with plant height $(r=0.19)$ but had a high correlation with leaf area $(r=0.53)$ (Table 5). In white clover Bortolini et al. (2006) found a high correlation between stolon diameter and plant height and leaf area and stolon diameter.

In the second evaluation, a positive correlation was found between stolon length and plant height $(\mathrm{r}=0.58$, Table 4). This is an example of a significant correlation with a low biological significance. Total dry matter was also positively correlated with plant diameter $(r=0.61)$, plant height $(\mathrm{r}=0.55)$, number of secondary stolons $(\mathrm{r}=0.54)$ and stolon length $(\mathrm{r}=0.56)$ (Table 4). In white clover Bortolini et al. (2006) also found that plants with lengthier stolons produced more total dry matter and Eisinger and Paim (1994) verified that plants that grew less in height produced less dry matter. The high and positive correlation found in $T$. riograndense between total dry matter and plant diameter and total dry matter and number of secondary stolons indicate that wider plants with many secondary stolons produce more total dry matter. On the other hand, leaf area and total dry matter were poorly correlated $(r=0.20$, Table
4 ), contrary to what was verified in white clover (Rosso and Pagano, 2001; Bortolini et al., 2006).

Genetic divergence analysis (Mahalanobis distance, detailed results not presented) showed accessions 11 (small leaves, few stolons and nodes, low DM production in the first cut, intermediate in the second) and 71 (large leaves, many stolons and nodes, good production in the first cut but low in the second) (Tables 2 and 3 ) to be the most divergent (71.11 divergence) both collected in the same region (Table 1). The smallest divergence was 1.30 between accessions 19 and 64, collected in two distinct regions. Both accessions were very similar in both evaluations (Tables 2 and 3).

Tocher method, using the genetic similarity expressed by Mahalanobis distance, produced 13 groups (Tables 2 and 3), one with five accessions (1, 29, 59, 42 and 66), another with four (10,41, 53 and 18), two with three accessions (11, 19 and 45; 30, 47 and 50), five with two accessions (15 and 33; 3 and 20; 17 and 43; 49 and 71; 23 and 64) and the other four with one accession each, reflecting the high variability of $T$. riograndense, what is to be expected in a wild allogamous species.

The dendrogram of genetic dissimilarity based on the Euclidian distance separated four groups when the average distance $(0.90)$ was used as cutting point (Figure 2): group 1 (accessions1, 18, 30, 23, 42, 49, 46, 19, 64, 3, $47,66,20,10,11,33,41,45,15,21$ and 29), group 2 (accessions $17,72,59,67$ and 43 ), group 3 with two accessions (50 and 71) and group 4 with only one accession (53). Accessions belonging to different groups (50 and 71, group $3 ; 53$, group $4 ; 72,59$, and 67 , group $2 ; 1,11,64$ and 66, group 1), were all collected in the same area (Table 1 ), outlining the high variability of $T$. riograndense in the region where the species is more common and abundant. On the other hand, very similar accessions such as 3 and

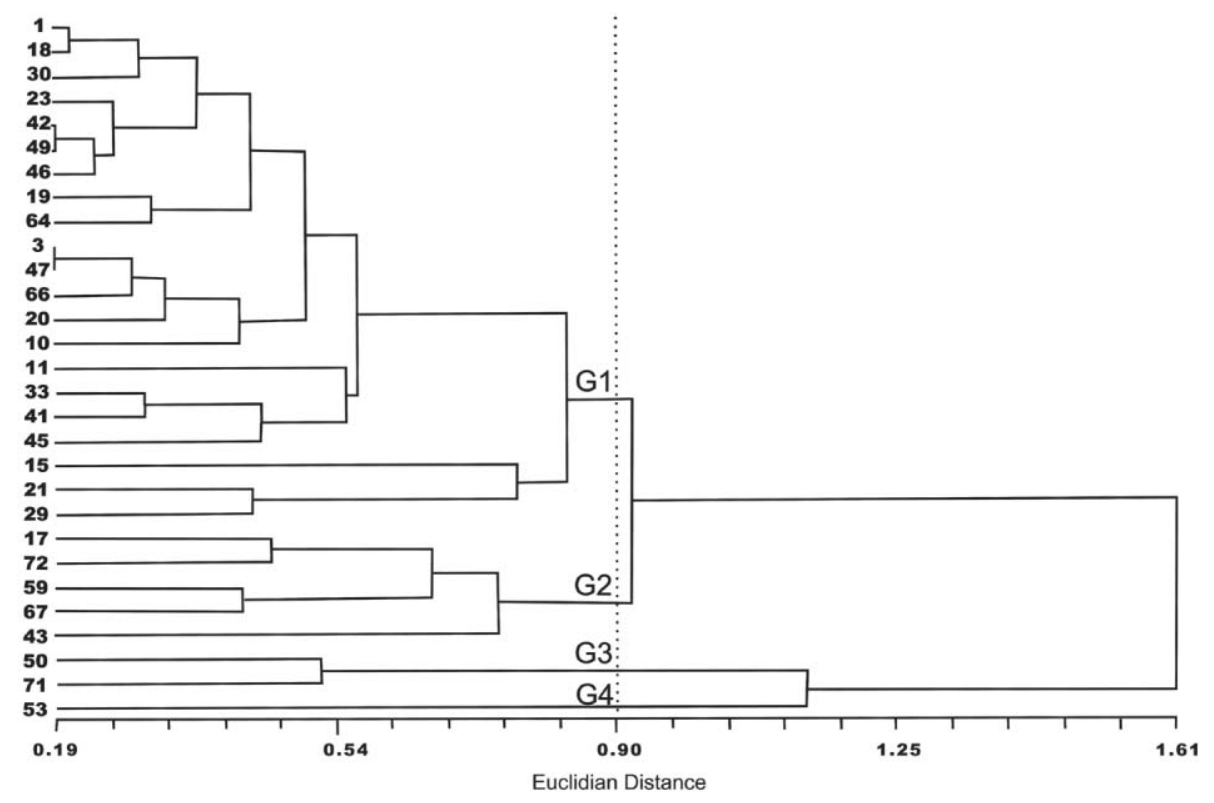

Figure 2 - Dendrogram of genetic dissimilarity based on Euclidian distance, for 29 accessions of T. riograndense. The dashed line points to the average distance and cutting point. G1, G2, G3 and G4 indicate the four groups. 
Table 5 - Relative contribution of each characteristic for divergence among T. riograndense accessions.

\begin{tabular}{lc|}
\hline Characteristic & Value (\%) \\
\hline Dry matter production, first cut & 20.8 \\
Number of secondary stolons, first evaluation & 12.3 \\
Leaf area & 11.1 \\
Number of nodes per primary stolon & 10.9 \\
\hline Length of primary stolons, first evaluation & 8.7 \\
\hline Plant diameter, first evaluation & 8.5 \\
\hline Internode length & 6.3 \\
Plant height, first evaluation & 5.1 \\
\hline Number of primary stolons, second evaluation & 4.6 \\
\hline Petiole length, first evaluation & 2.7 \\
Dry matter production, second cut & 1.9 \\
\hline Plant height, second evaluation & 1.8 \\
Number of primary stolons, second evaluation & 1.6 \\
Stolon diameter & 1.2 \\
\hline Number of secondary stolons, second evaluation & 1.1 \\
\hline Length of primary stolons, second evaluation & 0.7 \\
\hline Plant diameter, second evaluation & 0.4 \\
\hline
\end{tabular}

47, 42, 49 and 46 (Figure 2) were collected from small populations more or less near urban areas, where agriculture is very intensive, indicating a reduction of genetic variability. As an exception the similar accessions 1 and 18 were collected far apart (Table 1, Figure 1). Therefore, in T. riograndense, geographic diversity not necessarily implies in genetic diversity. The same was found by Bortolini et al. (2006) for white clover, but in other species as red clover ( $T$. pratense), accessions were grouped according to their geographic origin (Greene et al., 2004; Rosso and Pagano, 2005).

Dry matter production in the first cut was the characteristic that most contributed $(20.80 \%)$ to accessions divergence followed by number of secondary stolons $(12.30 \%)$, leaf area $(11.07 \%)$, and number of nodes per primary stolon $(10.93 \%)$ (Table 5). The characteristics that less contributed were plant diameter $(0.40 \%)$ and length of primary stolon $(0.74 \%)$ in the second evaluation. Dry matter production, number of nodes per primary stolon and number of secondary stolons in the first evaluation and leaf area contribute with $55.10 \%$ for the accessions divergence indicating that these characteristics together can discriminate the accessions and should be priorized in future works as they can reduce the time and resources needed to select desirable accessions and at the same time improving selection success. Choosing more divergent and with interesting agronomic characteristics accessions, for controlled crosses, would optimize the search for superior genotypes in a plant breeding program. On the other hand, those characteristics with little contribution to accessions divergence should not be considered. In white clover, Bortolini et al. (2006) reported that leaf area, plant height, flowering intensity and dry matter production contributed more to discriminate accessions. Flores et al. (2004) considered phenology, plant height and diameter and Caradus et al. (1989) indicated leaf area and cyanogenesis as the most important aspects to differentiate groups.

In the present study, the great contribution of dry matter production and number of secondary stolons in the first evaluation, to accessions divergence could be related to an earlier beginning of forage production in some accessions, which is an interesting charateristic to select aiming at the species improvment. As the plants did not flower during the experimental period, it is not possible to conclude about the importance of flowering to accessions divergence in $T$. riograndense. The absence of flowering in the present work was not totally unexpected as from previous observations when $T$. riograndense seeds were germinated in December, the derived plants flowered in October, but when germination ocurred in May-June the plants flowered only the next year. Therefore, T. riograndense probably needs a certain amount of degrees-day to be able to turn from the vegetative to the reproductive stage.

Plant height did not contribute much $5.08 \%$, Table $5)$ to accessions divergence reflecting the generally prostrate habit of the species and its relatively low stature when compared to other Trifolium species. Plants were cultivated isolated, and it favoured diameter growing, due to the absence of competition, as already mentioned by Flores et al. (2004) for white clover.

Leaf area may be a good indirect parameter to select accessions with good dry matter production and persistence. In the present study, however, accessions with large leaf area and high petioles length were not those with the 
highest total dry matter production (Tables 2 and 3). On the other hand, accessions with intermediate leaf area and medium petiole length $(67,47,42,33,29$ and 1), together with two accessions with small leaves (64 and 66) were those with highest total dry matter production, indicating a negative correspondence between leaf size and number. Those accessions with highest dry matter production in the first cut, therefore more precocious $(71,67,50$ and 43 , all with large leaves except 67) had a lot os senescent material at the end of the experimental period.

This is the first time that a large number of $T$. riograndense accessions are assessed for a broad range of characteristics, even if only in one year of evaluations. The results clearly show that in Southern Brazil pastures there is an invaluable native germplasm pool of a native legume forage species. This resource must be better studied (as with field plots and longer evaluations) in order to effectively select accessions with superior forage characteristics, to include these accessions in plant breeding programs and possibly, in a not far future, develop $T$. riograndense cultivars. And, as important as the utilization of the species, should be its conservation. For both, use and conservation, the integration of traditional techniques with modern ones, as molecular markers, would be outstanding.

\section{Acknowledgements}

The authors wish to thank the Conselho Nacional de Desenvolvimento Científico e Tecnológico (CNPq, Brazil), and the Fundação de Amparo à Pesquisa do Estado do Rio Grande do Sul (FAPERGS, Brazil), for Research, $\mathrm{PhD}$ and Scientific Initiation grants and financial support (CNPq Edital Universal proc. $n^{\circ}$ 471015/ 2007-15) and Dr. Luis Mauro Rosa for the help in leaf area determinations.

\section{References}

Albert, P.C.; Simms, E.L. 2002. The relative advantages of plasticity and fixity indifferent environment: when is it good for a plant to adjust. Evolutionary Ecology 16: 185-197.

Alcântara, P.B.; Bufarah, G. 1988. Forages Plants: Grasses and Legumes. Nobel, São Paulo, SP, Brazil. (in Portuguese).

Alves, M.I.F.; Machado, A.A.; Zonta, E.P. 1993. Special topics in experimental statistics using SANEST (Statistical Analysis System for Microcomputers). p. 1-110. In: UFRGS-Instituto de Matemática, ed. In: Simpósio de Estatística Aplicada à Experimentação Agronômica, UFRGS, Porto Alegre, RS, Brazil. (in Portuguese).

Becker, L.C.M.; Schifino-Wittmann, M.T.; Paim, N.R.; Riboldi, J. 1987. Observations on the mode of reproduction of Trifolium riograndense Burkart (Leguminosae). Ciência e Cultura 39: 304306. (in Portuguese).

Bortolini, F.; Dall'Agnol, M.; Schifino-Wittmann, M.T.; Trevisan, M.; Vieira, V.M.; Scheffer-Basso, S.M.; Montardo, D. 2006. Agronomic and morphological characterizations and genetic divergence on white clover germplasm. Revista Brasileira de Zootecnia 35: 1601-1610. (in Portuguese, with abstract in English).

Caradus, J.R.; Mackay, A.C.; Woodfield, D.; Bosch, V.D.; Wewala, S. 1989. Classification of a world collection of white clover cultivars. Euphytica 42: 183-196.
Cruz, C.D. 2001. Genes Program - Windows version: computer applicative in genetics and statistics. UFV, Viçosa, MG, Brazil. (in Portuguese).

Dias, P.M.B.; Julier, B.; Sampoux, J.P.; Barre, P.; Dall'Agnol, M. 2008. Genetic diversity in red clover (Trifolium pratense L.) revealed by morphological and microsatellite (SSR) markers. Euphytica 160: 189-205.

Eisinger, S.M.; Paim, N.R. 1994. Evaluation of clones of white clover under different levels of limestone and phosphorus in the soil. I. Rate of growth and production of forage. Revista Brasileira de Zootecnia 23: 383-393. (in Portuguese, with abstract in English).

.Ellison, N.W.; Liston, A.; Steiner, J.J.; Williams, W.M.; Taylor, N.L. 2006. Molecular phylogenetics of the clover genus (Trifolium-Leguminosae). Molecular Phylogenetics and Evolution 39: 688-705.

Flores, R.A.; Schefer-Basso, S.M.; Dall'Agnol, M. 2004. Morphophysiological characterization of white clover (Trifolium repens L.) genotypes. Agrociência 8: 21-28. (in Portuguese, with abstract in English).

Greene, S.L.; Gritsenko, M.; Vandemrk, G. 2004. Relating morphologic and RAPD marker variation to collection site environment in wild populations of red clover (Trifolium pretense L.). Genetic Resources and Crop Evolution 51: 643653.

Gustine, D.L.; Voigt, P.W.; Brummer, E.C.; Papadopoulos, Y.A. 2002. Genetic variation of RAPD markers for north american white clover collections and cultivars. Crop Science 42: 343347

Jahufer, M.Z.Z.; Cooper, M.; Ayres, J.F.; Bray, R.A. 2002. Identification of research to improve the efficiency of breeding strategies for white clover in Australia: a review. Australian Journal of Agricultural Research 53: 239-257.

Kappel, A. 1967. Clovers: Species of Genus Trifolium. Secretaria da Agricultura do Rio Grande do Sul-Departamento de Produção Animal, Porto Alegre, RS, Brazil. (in Portuguese).

Mather, R.D.J.; Melhuish, D.T.; Herlihy, M. 1995. Trend in the global marketing of white clover cultiars. p. 7-14. In: Woodfield, D.R, ed. White clover: New Zealand's competitive edge. Lincoln University, Lincoln, New Zealand.

Moraes, C.O.C.; Paim, N.R.; Nabinger, C. 1989. Evaluation of the legumes from genus Trifolium. Pesquisa Agropecuária Brasileira 24: 813-818. (in Portuguese, with abstract in English).

Nabinger, C. 1980. Techniques of improvement of the native pastures of Rio Grande do Sul. 1980. p. 28-58. In: FARSUL, ed. Anais do Seminário Sobre Pastagens: "De Que Pastagens Necessitamos”. FARSUL, Porto Alegre, RS, Brazil. (in Portuguese).

Nabinger, C. 2006. Management and productivity of native pastures from the Brazilian subtropic. p. 25-77. In: Dall'Agnol, M.; Nabinger, C.; Rosa, L.M.; Silva, J.L.S.; Santos, D.T.; Santos, R.J., eds. In: Simpósio de Forrageiras e Produção Animal. UFRGS-Faculdade de Agronomia, Porto Alegre, RS, Brazil. (in Portuguese).

Rolfh, F.J. 2001. NTSYS-pc: Numerical Taxonomy and Multivariate Analysis System: Version 2.1. Exeter Software, New York, NY, USA.

Rosso B.S.; Pagano, E.M. 2001. Collection and characterization of naturalized populations of white clover (Trifolium repens L.) in Argentina. Genetic Resources and Crop Evolution 48: 513-517.

Rosso B.S.; Pagano, E.M. 2005. Evaluation of introduced and naturalised populations of red clover (Trifolium pretense L.) at Pergamino EEA-INTA, Argentina. Genetic Resources and Crop Evolution 52: 507-511.

Sanderson, M.A.; Byers, R.A.; Skynner, R.; Elwinger, G.F. 2003. Growth and complexity of white clover stolons in response to biotic and abiotic stress. Crop Science 43: 2197-2205.

Schifino, M.T. 1983. Chromosome numbers and meiotic behavior in five native Brazilian forage legume species. Revista Brasileira de Genética 6: 357-362. 
Schifino, M.T.; Moraes-Fernandes, M.I.B. 1987. Induction of polyploidy and cytological characterization of autotetraploids of Trifolium riograndense Burkart (Leguminosae). Euphytica 36: 863-872.

Schifino, M.T., Moraes-Fernandes, M.I.B. 1988. Chromosome numbers, karyotypes and meiotic behavior of populations of some Trifolium (Leguminosae) species. Brazilian Journal of Genetics 11: 379-390.

Schneiter, O.; Rosso, B.; Corletto, M. 2009. Attributes related to seasonal herbage growth in white clover. Scientia Agricola 66: 20-27.

Souza, E.H.; Paim, N.R.; Schifino-Wittmann, M.T.; Riboldi, J. 1988. Morphological and physiological characterization of diploid and tetraploid forms of Trifolium riograndense in comparison with Trifolium repens and Trifolium polymorphum. Pesquisa Agropecuária Brasileira 23: 599-607. (in Portuguese, with abstract in English).
Thomas, R.G. 1980. Grwoth of the white clover plant in relation to seed production. p. 56-63. In: Lancashire, J.A., ed. Herbage seed production. Editorial Service, Auckland, New Zealand.

Zohary, M.; Heller, D. 1984. The Genus Trifolium L. The Israel Academy of Sciences and Humanities, Jerusalem, Israel.

Received June 15, 2009

Accepted May 14, 2010 